\title{
HR OUTSOURCING SUCCESS: DOES PARTNERSHIP QUALITY VARIABLES MATTER?
}

\author{
Elaine Ee ${ }^{1}$, Hasliza Abdul Halim ${ }^{2}$, Thurasamy Ramayah ${ }^{3}$ \\ School of Management, Universiti Sains Malaysia, Minden,11800 Penang, Malaysia \\ E-mails: 1leehtjohn@yahoo.co.uk; ${ }^{2}$ haslizahalim@usm.my (corresponding author); \\ 3ramayah@usm.my
}

Received 11 August 2011; accepted 08 December 2011

\begin{abstract}
Recently, increased attention has been paid to partnership quality in outsourcing strategy. However, research of partnership quality on the outsourcing of human resources (HR) is very limited. Therefore, this research aims at examining the relationship between partnership quality variables (business understanding, trust, commitment, communication and top management) and the success of HR outsourcing. The sample is obtained from a cross sectional survey and the sample studied are 96 manufacturing organizations in Penang, Malaysia. Results indicate that most of the organizations that outsourced HR functions were from electronic and electrical industry. The analyses also show that partnership quality variables such as trust, business understanding and communication have significant positive impact on HR outsourcing success. The study concluded that HR outsourcing as a competitive strategy in Malaysia is still relatively new and probably many of its potential benefits are not fully understood. Therefore, by understanding the relationship with the service providers, the organizations are able to achieve outsourcing success by identifying areas of expected benefits and improvements.
\end{abstract}

Keywords: human resource management, outsourcing, partnership quality, outsourcing success.

Reference to this paper should be made as follows: Ee, E.; Halim, H. A.; Ramayah, T. 2013. HR outsourcing success: does partnership quality variables matter?, Journal of Business Economics and Management 14(4): 664-676.

JEL Classification: M120 L140 L240.

\section{Introduction}

The business environment is evolving and to remain competitive, organizations have to constantly reinvent and reinforce their current operations with new ideas (Ok 2011). The organizations also are compelled to scout for new ways to generate value. The world has embraced the phenomenon of outsourcing and many organizations have adopted the principles of outsourcing to assist them expand into other markets (Wahrenburg et al. 2006). Consistent with a growing trend toward the outsourcing of activities traditionally performed in-house, many HR activities are now being outsourced (Lieven, De Corte 
2008). HR outsourcing takes place when an organization contracts with an HR vendor to perform HR activities (Greer et al. 1999).

The market for the service providers of outsourced services is growing rapidly and concurrently HR outsourcing has evolved from only having a single source, to a situation where multiple service providers can be easily contracted to satisfy the difference needs of the organizations (Lilly et al. 2005). In fact, the Malaysian government has shown some support to encourage the growth of shared services outsourcing (SSO) industry (Hewitt Association 2006). Since HR outsourcing development in Malaysia has not been intensively studied, managers may still have lack of knowledge on how to select the right service providers and to manage the outsourcing relationship. To many organizations, managing the relationships between organizations and service providers has become increasingly complex. This is because both parties may have different desires and agenda when developing and maintaining HR outsourcing relationships (Lieven, De Corte 2008). Moreover, the hidden cost of constantly having to monitor the outsourcing activities seems to hinder long-term commitment between the organizations and the service providers (Elmuti, Kathawala 2000).

Additionally, a poor choice of outsourcing partners can also hamper the success of outsourcing relationship (Elmuti, Kathawala 2000; Tapiero 2006). Many organizations fail to select the right partners and are not able to build a solid relationship with their service providers. Therefore to ensure on the successful relationship with the service providers, organizations must be aware that outsourcing partners should be selected based on their expertise in the operations, their cultural fit with the organizations, ability to establish strategic alliances and their willingness to adopt the philosophy that they are the organization partners may help alleviate this problem (Lau, Hurley 1997; Tapiero 2006). Along these lines, both parties need to develop a certain mechanism to strengthen HR outsourcing relationship and at the same time to consider outsourcing relationship to function more as partnership (Elmuti 2003; Lee, Huynh 2005).

Nevertheless, the existing literature on partnership seems to take the relationship of partnership quality and outsourcing success for granted (Lee 2001; Lee, Huynh 2005). In fact, there is almost next to none study has been done on the partnership quality of HR outsourcing. There should be validation whether HR outsourcing is successful when high-quality partnership exists. High quality may be a necessary condition for outsourcing success, but not a sufficient condition (Khong 2005). Consistent with the above argument, this study was designed to explore the factors of partnership quality in the context of HR outsourcing that may lead to outsourcing success. Since the trend of HR outsourcing in Malaysia is increasing (Hewitt Associations 2006) and the service providers are taking increasing responsibility in the realms of many HR functions that have traditionally remained in-house, it is imperative to understand this organizationservice provider relationship.

The paper is organized in the following manner: the next section reviews the HR outsourcing literature and develops the hypotheses; the third section presents the method used in the study; the fourth section highlights overall results of the study and the final section presents the discussion, limitations and conclusion. 


\section{Literature review}

\subsection{Outsourcing the HR function}

Outsourcing in general can be defined as the purchase from external vendors of a valuecreating activity that either was or could have been done in-house (Gilley, Rasheed 2000). Consequently, the outsourcing of HR activities is the practice of turning overall or part of an organization's HR function to external providers (Pelham 2002; Adler 2003). The trend suggests that outsourcing initially encompasses small segments of the HR function, particularly the non-core activities such as payroll and benefits administration (Adler 2003). This, however, has grown to include many other aspects of the HR function including core activities like HR planning and development (Quinn 1992; Stroh, Treehuboff 2003). Other activities that are amenable to outsourcing include training, recruitment, compensation, relocation and HR information systems (Lever 1997; Gilley et al. 2004). Regardless of what HR activities being outsourced, the organization will gain the maximum benefits from these activities as long as they are able to establish good relationship with their service providers. Those who work hard at partnering with the outsourced supplier has gained more success than those who looked at outsourcing as a way of dumping transactional work on an external party (Oshima et al. 2005).

\subsection{Partnership quality}

A part of the knowledge on building successful partnership in HR outsourcing is becoming a dilemma for HR outsourcing. HR practitioners lack of the know how in selecting their outsourcing vendors and there are also concerns on how they should manage this outsourcing relationship (Lee, Kim 1999). In the less developed market some organizations are even reluctant to establish a partnership type in their outsourcing agreement although this method has been proposed to be the most effective method to achieve competitiveness. The most frequently reported problem in the outsourcing relationship among clients and their HR vendors is the inability to express and describe in detail what they require from the vendors (Galanaki, Papalexandris 2005). This scenario will lead to conflict and inefficiency in the outsourced activity. Partnership involves two parties or more, namely service receivers and service providers. The service receivers are defined as the entities, units or employees who will use the service provided by the outsourcer whether they directly consume or indirectly consume the services. Whereas, the service providers are the party to whom the HR processes is outsourced (Lee, Kim 1999). This research measures the success of HR outsourcing from the perspective of the service receivers. This is because the service receivers are the decision-makers who decide on the reasons to outsource. They are the best person to judge if the outsource motivation has been met and if this strategy has been successful. They are assumed to have the most holistic view on outsourcing functions and to have the best insight on how the outsourcing relationship should be run (Ooi 2005).

Partnership allows two organizations to achieve key organizational objectives and build competitive advantage in their respective industries Grover et al. (1996). Therefore, it is interesting to study if HR outsourcing success would be affected by the quality of 
the partnership. Quality can be described as fitness of use. Partnership quality exists when relationships serve its intended function and is successful in meeting objectives of both parties. Lee and Kim (1999) proposed that partnership has its own factors to represent quality. They found that there are several variables that influence the degree of partnership quality, and that the degree of partnership quality is related to the outsourcing success. They identified five factors that make up partnership quality, which are trust, business understanding, and benefit and risk sharing, conflict and commitment. Anderson and Narus (1990) in their research also found that variables such as trust, communication and top management cooperation can lead to higher quality partnership.

\subsection{Outsourcing success}

Successful partnership enables the organizations to achieve organizational objectives and to build a competitive advantage that each organization could not easily attain by itself (Lee, Kim 1999; Khong 2005). Outsourcing success is defined as the satisfaction with the benefits attained by an organization as a result of deploying HR outsourcing (Grover et al. 1996). It has been suggested that it is possible to identify outsourcing success from the business perspective and user perspective (Lee, Kim 1999). Business performance can be measured by the qualitative impact of strategic and technological improvement and the quantitative improvement in terms of economic returns. Kim and Chung (2003) posit that there are two indicators for outsourcing success namely satisfaction and perceived benefits. Satisfaction involves evaluation of all aspects of the perceived effectiveness of the interorganizational relationship. In contrast, perceived benefits are clients firm's perception of benefits gained from a specific outsourcing relationship.

\section{Theoretical perspective and hypotheses development}

Resource dependence theory explains organization motivation for outsourcing from the economic point of view. This is because organizations are made up of a collection of production resources such as physical, human, technology and capital. Since supply is scarce, organizations have to maximize resources efficiently. To overcome scarcity of resources organizations may need to acquire external complementary resources and search for other capabilities. After thorough evaluation of current resources deficiencies the organizations can consider entering into exchange relationships with other organizations in the environment (Grover et al. 1996). Resource dependence theory posits that it is possible for seeking resources from vendors to supplement in-house competencies, rather than total acquisition of the resources. Both transaction cost theory (Ang, Straub 1998) and relational exchange theory (Kim, Chung 2003) are also reviewed to provide an insight to outsourcing from an interorganizational relationship (IOR) perspective. Outsourcing can be characterized as an IOR since two parties from different organizations work together (Kim, Chung 2003). Transaction cost theory states that there are economic costs involved in the transactions between two or more entities.

From this outset, it is important to distinguish the concept of partnership quality from 
that of outsourcing success, and to explore on whether outsourcing is successful when high quality partnership exists. From all the past literature studied, elements such as trust, business understanding, commitment, communication and top management support were identified as the factors that contribute to partnership between organizations. The five elements are used to test the hypothesized relationship between partnership quality and the success of HR outsourcing activity. The communication quality becomes an effective role in partnership. Effective communication between partners is essential in order to achieve the intended objectives. In fact, it will lead to better informed parties, which in turn should make each party is more confident in the relationship and more willing to maintain it successfully (Lee, Kim 1999). Apart from that, top management has to play an important role to overcome the inevitable divergence of interest between participants and at the same time to share an understanding of the benefits of collaboration (Rai, Borah, Ramaprasad 1996). When organization embarks on outsourcing relationship and selects a particular service provider, the organization must be ready to maintain the relationship over a period of time. The need to maintain such business relationships requires a form of long term relationship based on trust. Both parties need to believe one another in order to perform actions that will result in positive outcomes for the organizations (Lee, Kim 1999; Willcock, Chong 1995). Additionally, commitment also plays a critical role in the development of a long-term relationship and in facilitating an exchange relationship. These relationships must contain a certain degree of sincerity, pledge or promise of relationship continuity between partners. Therefore, trust and commitment are the basic concept of partnership-style relationship and these factors increase confidence in the relationship, in turn lead to outsourcing success (Lee 2001; Moore 1998). Finally, outsourcing success will be motivated by business understanding whereby both parties have the ability to understand each other in terms of the operation dealings, behaviours goals, business procedures and policies (Hsu et al. 2005).

In short, partnership quality helps foster cooperative relationship based on trust, business understanding, commitment, communication and the top management which is critical to determine the success of outsourcing particularly in the area of human resources. Fig. 1 exhibits these relationships.

From the proposed research model below hypotheses were formed to examine the relationship between the elements of partnership quality and HR outsourcing success.

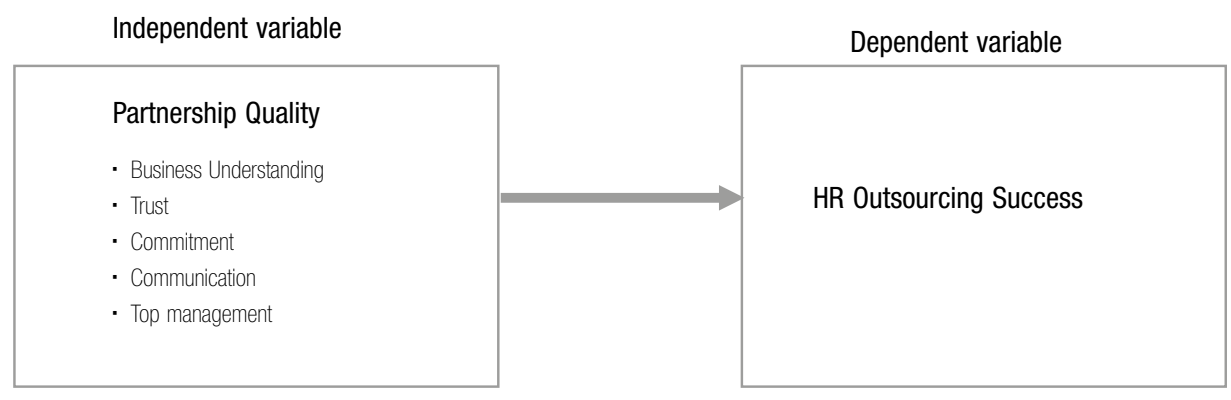

Fig. 1. Research model 
H1: There is a positive relationship between trust and outsourcing success.

H2: There is a positive relationship between business understanding and outsourcing success.

H3: There is a positive relationship between commitment and outsourcing success.

H4: There is a positive relationship between communication and outsourcing success.

H5: There is a positive relationship between top management support and outsourcing success.

\section{Methodology}

\subsection{Population and sample}

This study used a mail survey questionnaire to obtain data. The population of this study was manufacturing organizations in Malaysia that outsourced their HR function(s). These organizations were selected from the Federation of Malaysia Manufacturer (FMM) Directory. The questionnaires were targeted to the head of HR department, or the person responsible for HR of Malaysian manufacturing organizations that engaged with HR outsourcing. Purposive sampling method was used in which the organizations were first contacted to enquire on their engagement with HR outsourcing. Thus, only organizations that outsourced HR functions were selected to participate in this study.

\subsection{Measurement instrument}

\subsubsection{Outsourcing success}

Outsourcing success, the dependent measure of this research, refers to the overall organizational advantage obtained from HR outsourcing. The determination of outsourcing success was adopted from the instrument of Grover et al. (1996) and was designed on the five point Likert scale ( $1=$ strongly disagree and $5=$ strongly agree $)$.

\subsubsection{Partnership quality}

The measurements for the variables used in the questionnaire were adopted from Lee and Kim's (1999). The five point likert scale was also used to test the multi-item constructs for partnership quality such as trust, business understanding, top management support, communication and commitment. Factor analysis was conducted to check on the validity and reliability of the measurement scales. The computer software, Statistical Package for the Social Sciences (SPSS) version 14 was used to analyze and test hypotheses. From factor analysis, five factors of partnership quality were produced with factor loadings from 0.64 to 0.93 and with $\mathrm{KMO}$ and Barlette test of 0.80 and 0.00 respectively. The five factors contributed 73.51 percent to item variance. The cut off used for factor loadings was set at 0.5 to ensure that each item is only uniquely assigned to one only factor. The Cronbach's alpha of each factor is as follows:

1) Business understanding $\alpha=0.73$

2) Trust $\alpha=0.91$

3) Commitment $\alpha=0.71$ 
4) Communication $\alpha=0.81$

5) Top management $\alpha=0.87$

6) Outsourcing success $\alpha=0.80$

\section{Analysis and results}

\subsection{Profile of the respondents}

A total of 99 questionnaires were received at the end of the data collection process. Based on the initial expectation of 228 respondents from organizations responded positively that they outsourced at least one function, the response rate is approximately 43.42 percent. Although the response rate is less than 50 percent, Babbie (1973) suggested that, "a demonstrated lack of response bias is far more important than a high response rate". Three of the questionnaires returned were less then $30 \%$ completed by the respondents and hence were abandoned from the analysis. The final 96 completed sets of questionnaire were used in this study. Table 1 shows the profile of the respondents.

Table 1. Profile of the organizations that outsourced HR functions

\begin{tabular}{|c|c|c|}
\hline HR Outsourced Organizations & Number & Percentage \\
\hline \multicolumn{3}{|l|}{ Type of industry } \\
\hline Electronics/ Electrical & 28 & 28.1 \\
\hline Machinery/ Equipment & 18 & 18.8 \\
\hline Textile/Apparel & 6 & 6.3 \\
\hline Agriculture/Biotechnology & 5 & 5.2 \\
\hline Chemical & 4 & 4.2 \\
\hline Plastic/Rubber/Polymer & 10 & 10.4 \\
\hline Pharmaceuticals/ Healthcare & 9 & 9.4 \\
\hline Food Processing & 6 & 6.3 \\
\hline Computer/ Information Technology & 8 & 8.3 \\
\hline Automotive/ Automobile & 3 & 3.1 \\
\hline \multicolumn{3}{|l|}{ Positions } \\
\hline Assistant HR Officer & 5 & 5.2 \\
\hline Officer HR / Executive HR & 23 & 24 \\
\hline Assistant HR Manager & 21 & 21.9 \\
\hline HR Manager & 41 & 42.7 \\
\hline HR Senior Manager & 6 & 6.3 \\
\hline \multicolumn{3}{|l|}{ Number of HR employees } \\
\hline Less than 5 person & 36 & 37.5 \\
\hline $5-10$ person & 37 & 38.5 \\
\hline $11-15$ person & 13 & 13.5 \\
\hline $16-20$ person & 6 & 6.3 \\
\hline \multirow[t]{2}{*}{ More than 20 person } & 4 & 4.2 \\
\hline & Mean & S.D. \\
\hline Number of Workers & 1002.39 & 1896.42 \\
\hline Years of HR Outsourcing & 5.44 & 4.32 \\
\hline
\end{tabular}


Table 2. Profile of the HR functions outsource by respondents

\begin{tabular}{lccc}
\hline Functions & Response & Frequency & Percent \\
\hline \multirow{2}{*}{ Training } & No & 35 & 36.5 \\
\cline { 2 - 4 } & Yes & $\mathbf{6 1}$ & $\mathbf{6 3 . 5}$ \\
\cline { 2 - 4 } Recruitment & No & 40 & 41.7 \\
\cline { 2 - 4 } Compensation \& Benefits & Yes & $\mathbf{5 6}$ & 58.3 \\
\cline { 2 - 4 } & No & 80 & 83.3 \\
\hline \multirow{2}{*}{ Payroll } & Yes & $\mathbf{1 6}$ & $\mathbf{1 6 . 7}$ \\
\cline { 2 - 4 } & No & 72 & 75.0 \\
\cline { 2 - 4 } Employees Services & Yes & $\mathbf{2 4}$ & $\mathbf{2 5 . 0}$ \\
\cline { 2 - 4 } Employees Record System & No & 68 & $\mathbf{2 9 . 8}$ \\
\cline { 2 - 4 } & Yes & $\mathbf{2 8}$ & 63.5 \\
\hline \multirow{2}{*}{ Operator / Labor Supply } & No & 61 & $\mathbf{3 6 . 5}$ \\
\cline { 2 - 4 } & Yes & 53 & $\mathbf{4 4 . 8}$ \\
\cline { 2 - 4 } & No & $\mathbf{4 3}$ &
\end{tabular}

Most of the respondents $(28.1 \%)$ are from the electronics and electrical industry and 76 percent of the organizations employed less than $10 \mathrm{HR}$ employees. In terms of the position of the respondents, 42.7 percent of them are the HR managers and the mean period for the outsourcing of HR function is about 5 years with an average of about 1002 employees.

On the profile of the number of HR functions outsourced by the organizations, training was the most frequently outsourced function (63.5\%). The recruitment function records the second highest percentage at 58.3 percent, followed by operator/labour supply at 44.8 percent. The least outsourced function was compensation and benefits at 16.7 percent. Table 2 summarizes the various HR functions outsourced by respondents.

\subsection{The effect of partnership quality on outsourcing success}

Linear regression was performed to examine the direct relationship between partnership quality and outsourcing success. The result is presented in Table 3.

Table 3. Regression for partnership quality and outsourcing success

\begin{tabular}{lc}
\hline Independent Variable & Std Beta \\
\hline Trust & $0.47^{* * *}$ \\
\hline Business Understanding & $0.16^{*}$ \\
\hline Commitment & -0.02 \\
\hline Communication & $0.26^{* *}$ \\
\hline Top Management Support & 0.08 \\
\hline R Square & 0.46 \\
\hline Adj. R Square & 0.43 \\
\hline Sig. & 0.00 \\
\hline Durbin Watson & 2.11 \\
\hline F value & $15.29^{* * *}$ \\
\hline
\end{tabular}

Note: ${ }^{*} \mathrm{p}<.10,{ }^{* *} \mathrm{p}<.05,{ }^{* * *} \mathrm{p}<.01$ 
The results show that 46 percent of the variations in outsourcing success can be explained by the partnership quality variables. The significance of $\mathrm{F}$ change is 0.00 , thus this implies that there exist significant relationship between partnership quality and outsourcing success. The results show support for hypotheses $\mathrm{H} 1, \mathrm{H} 2$ and $\mathrm{H} 4$. Trust is found to be positively and significantly correlated at 1 percent level $(\beta=0.47)$. The beta value of 0.47 indicates that trust is the most influential variable in explaining outsourcing success. As a result hypothesis H1 is supported. In addition, business understanding also had a significant impact on the success of outsourcing $(\beta=0.16)$. Therefore, hypothesis $\mathrm{H} 2$ was also supported. H4 was also supported in which communication had a significant relationship with outsourcing success $(\beta=0.26)$. In contrast, commitment and top management support were found to be not statistically significant with the outsourcing success. As a result hypothesis H3 and H5 were not supported.

\section{Discussions}

This study has provided a useful step towards a better understanding of the relationship between the organizations and service provider in the context of human resources. The results demonstrated that there was a strong positive relationship between trust and outsourcing success. This result is consistent with previous works of other researchers such as Lee and Kim (1999), Parker and Russell (2004), Lee and Huynh (2005), Gurung and Prater (2006). Trust is an important component in partnership quality because it will result in positive outcomes for the both parties. In fact, trust is a central aspect of a successful outsourcing relationship from the beginning of a relationship to the end (Anderson, Weitz 1989; Moore 1998). An absence of trust can lead to disruption of information flow, coordination problems and conflicts between organizations.

Business understanding had a positive significant association with outsourcing success. This indicates that business understanding is an important factor in an outsourcing agreement because of the shared responsibility, benefits and risks involved in the process. Essentially, the organizations' profit is partly depending on the ability of their outsourcing partner to support their business operations. Understanding clients' expectation and knowing the organization's capability in providing these services will lead to a viable partnership (Lee, Kim 1999).

Communication also had a significant relationship with outsourcing success. This signifies that communication is a critical activity that allows information flow between different parties during different stages of outsourcing activity (Galanaki, Papalexandris 2005) In essence, communication skills help the organizations to communicate their wants and needs accurately to their service providers which allow things to be done right the first time. This practice will prevent loss of time and wastage of resources thus leading to a better outsourcing outcome. Therefore, meaningful discussion is vital in planning, goal setting, implementation, coordination and performance evaluation.

However, the results show that neither commitment nor top management support has a significant association with HR outsourcing success. This finding is not consistent with the findings of Lee and Kim (1999). It is possible that for Malaysian organizations, the 
role of commitment is overshadowed by other components of partnership quality such as trust and business understanding. Initial trust will lead both parties to the disposition to believe that the other party would fulfill the commitment and behave in a predictable way (Lee, Huynh 2005). Business understanding and communication serves as important economic and cognitive cues in outsourcing success. Firms were more dependent on the higher trust, stronger business understanding and good communication as drivers to positively influence outsourcing success. As for top management support, it can be assumed that HR practitioners are able to manage the outsourcing relationship proficiently without the assistance of the top management team. This may be due to the fact that the employees themselves are responsible or have a positive attitude in making outsourcing a success. Once top management have decided what functions to outsource they typically delegate the commitment to their middle management to manage and administer the outsourcing activities since they believe that their employees have the capability and functional knowledge in making it a success.

\subsection{Implications}

A number of implications can be derived from this study. It is common to find that organizations outsource more than one HR function and in fact most of them outsourced training and recruitment functions. However, Malaysian organizations were found to engage with HR outsourcing for about five years only. This indicates that HR outsourcing as a competitive strategy in Malaysia is still relatively new and probably many of its potential benefits are not fully understood. Among the items introduced were enhanced competency, increased core function focus, better cost control, increased efficiency, increased used of latest technology and leverage best practices. It is important to understand the component of partnership quality in order to develop a solid relationship with the vendor, irrespective of whether one specific HR function is outsourced or more and ultimately the most impact on HR outsourcing success.

Trust has the strongest impact and this suggests to managers that they can use trust as a foundation for successful outcomes in the outsourcing relationship with their partners. Frequently, outsourcing strategies are viewed negatively by the service receivers because of the fear of losing control over the process. It takes time to build trust in a partnership. Therefore, initial trust would be a qualitative attribute that managers should look for in their selection of vendors for outsourcing. For organizations that are already practicing outsourcing they should integrate activities such as information exchange on long range plans, benefits and risk sharing, mutual problems and knowledge sharing that can enhance the partnership trust level and improve the working relationship. Apart from that, organizations must also understand that there should be open and frequent communication between service providers and service receivers. This is because proper communication facilitates negotiation, transfer of information and resolves possible conflicts in any outsourcing relationship. Managers should therefore insist on timely and creditable communication channels.

This study also assists HR managers that business understanding should become an 
extension of a particular organizational work culture when they handle outsourced HR functions such as training, recruitment, employee records and other functional tasks. In this matter, occasionally conflict and disagreement in needs may hamper outsourcing success. Consequently, understanding of roles and responsibilities of the service providers and service receivers is a crucial aspect of partnership quality that requires special managerial attention. Prior to entering a partnership, the business mission of both parties, need to be properly understood. This could be achieved through having a set of assigned goals for each specific milestone in the relationship to serve as check points. In short, this study has made important contributions both to HR managers and researchers by filling gaps in the area of partnership quality for outsourcing HR functions.

\subsection{Limitation and future research}

There are a few limitations in this study. Firstly, the sample size is small due to the low response rate and time constraint. Obtaining more robust results would require a larger sample size. Secondly, in this research, one questionnaire represents an organization, thus the person who fill up the questionnaire may be biased and non-representative. Next, limited numbers of similar research has been carried out on this topic. Therefore to overcome this limitation, this paper had included literature review from other industries mainly from the Information System (IS) and Information Systems (IT) industry. Lastly, the effect of partnership quality on HR outsourcing success of this study is limited to only manufacturing firms in Malaysia.

More research can be conducted to examine the proposed model on HR outsourcing success. Firstly, it would be interesting to extend this research to service industry for example in order to obtain more generalized findings. This can provide a better understanding of the growing trend of HR outsourcing in Malaysia. Next, analysis of the relationship between partnership quality and outsourcing success from the service provider's perceptive would also provide a broader perspective. It is also suggested that a longitudinal research be carried out to investigate the dynamic features of outsourcing partnership, as it will provide a more robust result than a snapshot research. Finally, more variables could be examined as an extension to this study. Other variables reflecting factors such as firm environment, strategic orientation, corporate philosophy, culture and organizational practice could be included.

\section{References}

Adler, P. S. 2003. Making the HRM outsourcing decision, MIT Sloan Management Review 45(1): 53-60.

Anderson, J. C.; Narus, J. A. 1990. A model of distributor firm and manufacturer firm working partnership, Journal of Marketing 54(1): 42-58. http://dx.doi.org/10.2307/1252172

Anderson, J. C.; Weitz, B. 1989. Determinants of continuity in conventional industrial channel dyads, Marketing Science 8(4): 310-323. http://dx.doi.org/10.1287/mksc.8.4.310

Ang, S.; Straub, D. W. 1998. Production and transaction economies and information system outsourcing, MIS Quarterly 22(December): 535-552. http://dx.doi.org/10.2307/249554

Babbie, E. R. 1973. Survey Research Methods. California: Wadsworth Publishing Company, Inc. 
Elmuti, D. 2003. The perceived impact of outsourcing on organizational performance, Mid-American Journal of Business 18(2): 33-41. http://dx.doi.org/10.1108/19355181200300010

Elmuti, D.; Kathawala, Y. 2000. The effects of global outsourcing strategies on participants' attitudes and organizational effectiveness, International Journal of Manpower 21(2): 112-128. http://dx.doi.org/10.1108/01437720010331044

Galanaki, E.; Papalexandris, N. 2005. Outsourcing of human resource management services in Greece, International Journal of Manpower 26(4): 382-396.

Gilley, K. M.; Rasheed, A. A. 2000. Making more by doing less: an analyzing of outsourcing and its effects on firm performance, Journal of Management 26(4): 763-790.

Gilley, K. M.; Greer, C. R.; Rasheed, A. A. 2004. Human resource outsourcing and organizational performance in manufacturing firms, Journal of Business Research 57(3): 232-240.

http://dx.doi.org/10.1016/S0148-2963(02)00304-1

Greer, C. R.; Youngblood, S. A.; Gray, D. A. (1999), Human resource management outsourcing: The make or buy decision, Academy of Management Executive 13(3): 85-96.

Grover, V.; Cheon, M. J.; Teng, J. T. C. 1996. The effect of service quality and partnership on the outsourcing of information system functions, Journal of Management System 12(4): 89-116.

Gurung, A.; Prater, E. 2006. A research framework for the impact of cultural differences on IT outsourcing, Journal of Global Information Technology Management 9(1): 24-44.

Hewitt Association. 2006. [Online], [cited 16 April 2011]. Available from Internet: http://www.hewittassociates.com/Intl/NA/en-US/Default.aspx.

Hsu, C. C.; Wu, C. H.; Hsu, J. C. H. 2005. Performance evaluation of information system outsourcing in Taiwan's large enterprise, Journal of American Academy of Business, Cambridge 6(1): 255-259.

Khong, K. W. 2005. The perceived impact of successful outsourcing on customer service management, Supply Chain Management: An International Journal 10(5): 402-411.

Kim, S.; Chung, Y. S. 2003. Critical success factors for IS outsourcing implementation from an interorganizational relationship perspective, The Journal of Computer Information Systems 43(4): 81-91.

Lau, R. S.; Hurley, C. N. 1997. Outsourcing through strategic alliances, Production and Inventory Management Journal 38(2): 52-70.

Lee, J. N. 2001. The impact of knowledge sharing, organizational capability and partnership quality on IS outsourcing success, Journal of Information and Management 38(5): 323-335.

Lee, J. N.; Huynh, M. Q. 2005. An integrative model of trust on IT outsourcing: from the service receiver's perspective, in Proceedings of the 9th Pacific Asia Conference on Information Systems, July 7-10, 2005, Bangkok, Thailand, 767-779.

Lee, J. N.; Kim, Y. J. 1999. Effect of partnership quality and IS outsourcing success: conceptual framework and empirical validation, Journal of Management Information System 15(4): 29-61.

Lever, S. 1997. An analysis of managerial motivations behind outsourcing practices in human resources, Human Resource Planning 20(2): 37-47.

Lievens, F.; De Corte, W. 2008. Development and test of a model of external organizational commitment in human resources outsourcing, Human Resource Management 47(3): 559-579. http://dx.doi.org/10.1002/hrm.20232

Lilly, J. D.; Gray, D. A.; Virick, M. 2005. Outsourcing the human resource function: environmental and organizational characteristics that affect HR performance, Journal of Business Strategies 22(1): 55-72.

Moore, K. R. 1998. Trust and relationship commitment in logistics alliances: a buyer perspective, International Journal of Purchasing and Materials Management 34(1): 24-37.

http://dx.doi.org/10.1111/j.1745-493X.1998.tb00039.x 
Ooi, E. 2005. A study on the effect of partnership quality on business process outsourcing for bank and financial institutions in Malaysia. Unpublished MBA dissertation. Post Graduate Studies, School of Management, University Science Malaysia, Penang.

Ok, S. T. 2011. International outsourcing: empirical evidence from the Netherlands, Journal of Business Economics and Management 12(1): 131-143.

http://dx.doi.org/10.3846/16111699.2011.555383

Oshima, M.; Kao, T.; Tower, J. 2005. Achieving post outsourcing success, Human Resource Planning 28(2): 7-11.

Parker, D. W.; Russell, K. A. 2004. Outsourcing and inter/intra supply chain dynamics: strategic management issues, Journal of Supply Chain Management 40: 56-68.

http://dx.doi.org/10.1111/j.1745-493X.2004.tb00178.x

Pelham, D. 2002. It is time to outsource HR?, Training 39(4): 50-3.

Quinn, J. B. 1992. Intelligent enterprise: a knowledge and service based paradigm for industry. New York: Free Press.

Rai, A.; Borah, S.; Ramaprasad, A. 1996. Critical success factors for strategic alliances in the information technology industry: an empirical study, Decision Sciences 27(1): 141-155.

http://dx.doi.org/10.1111/j.1540-5915.1996.tb00848.x

Stroh, L. K.; Treehuboff, D. 2003. Outsourcing HR functions: when-and when not-to go outside, Journal of Leadership and Organizational Studies 10(1): 19-28.

http://dx.doi.org/10.1177/107179190301000102

Tapiero, C. S. 2006. Strategic quality assurance, Journal of Business Economics and Management 7(1): 29-35.

Wahrenburg, M.; Hackethal, L. F.; Gellrich, T. 2006. Strategic decisions regarding the vertical integration of human resource organisations: evidence for an integrated $\mathrm{hr}$ model for the financial services and non-financial services in Germany, Austria and Switzerland, International Journal of Human Resource Management 17(10): 1726-1771. http://dx.doi.org/10.1080/09585190600964467

Willcocks, L.; Chong, J. C. 1995. Co-operative partnership and total IT outsourcing: from contractual obligation to strategic alliance?, European Management Journal 13(1): 67-78.

http://dx.doi.org/10.1016/0263-2373(94)00059-G

Elaine EE graduated with a Masters of Business Administration degree from the School of Management, Universiti Sains Malaysia. Her research work explored the HR outsourcing success from the key users perspectives. She is currently employed in a multinational company in Penang.

Hasliza Abdul HALIM PhD is currently a Senior Lecturer in Organizational Behaviour Section, School of Management, Universiti Sains Malaysia. She obtained her PhD from University of Malaya, Malaysia. Her research interests include strategic HRM, strategic management, business strategy and HR outsourcing.

Thurasamy RAMAYAH is currently a Professor at the School of Management in USM. He teaches mainly courses in Research Methodology and Business Statistics. Apart from teaching, he is an avid researcher, especially in the areas of technology management and adoption in business and education. His full profile can be accessed from http://www.ramayah.com 